\title{
Ewa Macura-Nnamdi
}

\section{Of Women and Decadence}

\section{Travel, Pleasure and Waste in Ella D'Arcy's "The Pleasure-Pilgrim"}

\begin{abstract}
This paper reads Ella D'Arcy's short story "The Pleasure-Pilgrim" as a text engaging with late-nineteenth century discourses of femininity and decadence as they are enacted in the realm of travelling, on one hand, and of decadent aestheticism, on the other. The particular narrative construction of the main heroine, Lulie, is seen here as problematising the gendering of the consumption/production dichotomy and as challenging the masculinist bias of the aesthetic transgressions of decadence. Given this, D'Arcy's story emerges here as a text that reveals how and why certain assumptions of late-Victorian aestheticism only made room for women as objects but never as subjects of decadent aesthetics.
\end{abstract}

Ella D’Arcy's story “The Pleasure-Pilgrim” $(1895)^{1}$ was first published in the Yellow Book and reprinted in her collection of short stories Monochromes (1895). Its heroine, Lulie Thayer, is an American traveller who, together with her confidante and chaperone, Miss Dodge, spends a couple of months at a German castle, changed into a "boarding-house" (59). There she meets a writer and aesthete - Mr. Campbell.

Fascinated with Lulie at first, Campbell loses interest when his friend, Mayne, reveals Lulie's scandalous reputation, which Lulie confirms with her unabashedly expressed love for Campbell. As her inward repulsiveness slowly mars her outward beauty, Campbell cannot conceal the disgust he feels at the confessions of love of the infatuated Lulie. The less Campbell is interested, the more Lulie is determined to convince him of her love. Irritated with Lulie's vexatious demands that he believe in her affection, Campbell jokingly dares her to barter her life for truth. Lulie shoots herself in an act that demonstrates her honesty. "The Pleasure-Pilgrim" is a story of degeneration, the degeneration of a virgin into a whore, of a woman into a New Woman, of beauty into ugliness, and of truth into lies.

1. Ella D'Arcy, "The Pleasure-Pilgrim," in The Eighteen-Nineties: A Period Anthology in Prose and Verse, chosen by Martin Secker with an introduction by John Betjeman (London: The Richards Press, 1948), 58-84. All parenthesized references are to this edition.

The AnaChronisT 17 (2012/13) 137-160 ISSN 1219-2589 (print) ISSN 2063-126X (web) 
According to Margaret D. Stetz, ${ }^{2}$ D'Arcy's narrative is a critique of the aestheticisation of women by male writers. Lulie Thayer, the heroine, is represented as a spectacular object of exchange and visual appreciation, whose body and history are subjected to men's harmful speculations. At the hands of two aesthete-connoisseurs (Campbell and Mayne), Lulie shifts from an innocent and pure, still to be explored, beauty to the rapacious ugliness of a fallen woman. A fatal seductress, Lulie not only transgresses the boundaries of gender propriety but she also threatens, as Stetz argues, the homosocial bond between Mayne and Campbell, and unlawfully usurps the position of an aesthete. Her tragic end is a consequence of flouting gender roles and expectations by appropriating the realm of aestheticism in which women could only take a passive position, and by laying claim to experiences traditionally reserved for men.

Along similar lines, Sarah E. Maier3 argues that in "The Pleasure-Pilgrim" D'Arcy exposes men's mythologizing of an idealized womanhood that leads to stigmatisation of those women who depart from the ideal. Where Lulie departs most visibly is in her open expressions of sexuality, which give rise to an inevitable conflict, the solution of which can only be Lulie's self-destruction. The despairing woman driven to suicide represents both the impossibility of her sexuality and the failure of resistance: "Lulie must die,"4 argues Maier, as she threatens the social order and men's position in it.

The first part of this paper, but for pleasure, looks at D'Arcy's "The PleasurePilgrim" as a story that rambles over the production/consumption divide as its heroine, Lulie Thayer, travels around Europe in search of pleasure and sensations. It is concerned with the effects produced when the decadent anti-productive and anti-utilitarian pose is adopted by a woman. Here, this pose comes to be assumed in travelling, a fruitless, and unlawful, consumption of the public realm which calls for productive inhabitation (itself marked by productivity) and thus removes her from its territory. Thus the narrative is steeped in, and progresses within, spatial economies consequential for the characters. What is brought to the fore is how space is marked by gender and how this gendering, in turn, comes to mark pleasure and aesthetic connoisseurship. Lulie's problematic relation to the public sphere of travellers does not so much complicate the assumptions of bourgeois marriage economy as it tampers with the logic that this sphere presupposes. It also brings up the poli-

2. Margaret D. Stetz, "Debating Aestheticism from a Feminist Perspective," in Women and British Aestheticism, ed. Talia Schaffer and Kathy Alexis Psomiades (Charlottesville and London: University of Virginia Press, 1999), 25-43.

3. Sarah E. Maier, "Subverting the Ideal: The New Woman and the Battle of the Sexes in the Short Fiction of Ella D’Arcy," Victorian Review 20.1 (1994) 35-48.

4. Maier, p. 46. 
tics of travel itself. Within this politics, travelling, one of the many ways of inhabiting the non-domestic space, can only be granted worth once it satisfies the demand of productiveness and proper use. Lulie is closer, therefore, to a mere tourist, a personage who, in the nineteenth-century discourses on travelling, frequently aligned with women, signals an unproductive cultural undertaking. Yet amidst the implica of Lulie's bold pilgrimage, D'Arcy's narrative retains a productive ambivalence which results from the tension between the positions she is made to occupy and the positions she herself chooses to assume. While Lulie searches for new experience and lays claim to aesthetic appreciation, she is nonetheless textualised as a fascinating realm for other travellers. Couched in imperial metaphors, the relation between Lulie and Campbell (the decadent connoisseur infatuated with Lulie) works along the lines demarcated by these metaphors whereby Campbell, in a truly colonial fashion, becomes a discoverer of, and an expert on, beauty while Lulie figures as a land discovered into a beautiful and pleasurable surface. Within the terms of this conquest she is also cast into an exoticised object of the fantasies of decadence. The doubleness of Lulie's narrative figuration, where she is, at once, a traveller and a territory travelled to, proves productive of undermining Campbell's privileged position and of problematising the gendering of the consumption/production dichotomy.

The second part, you don't know what you have lost!, engages with both Lulie's decadent femininity and her performance of decadence. Cast by men into the role of a typically decadent femme fatale, Lulie, at the same time, claims the poetics of decadence. The tension resulting from the encounter between these two conflicting narratives works to cast doubt on Campbell's cultural and aesthetic mastery. It also points out that the terms of a decadent, anti-bourgeois transgression prevent a woman from enjoying its benefits. Unless Lulie remains within the bounds prescribed by the parameters of a dangerous seductress, she offers an exquisite and sensational character, an object of aesthetic appraisal and others' speculations. Yet when she assumes a decadent pose she becomes subjected to certain practices of verification which demand that she shed the garb of decadence because it threatens masculine privileges and the logic on which they are based. While she comes to embody a hermeneutic model with which to read her performance of decadence, she at the same time disrupts the unproblematic correspondence between seeing and knowing, one that underlies men's aestheticism and constructs her into an embodiment of duplicity. This duplicity persistently renders her inordinate speech meaningless as it fails to conform to an economy productive of truth. Together with her unrestrained consumption of pleasure, her verbal excess aligns Lulie with wastefulness where what is wasted, and thus lost, are things which do not properly belong to her. It is because, within the bourgeois marriage economy, Lulie literally comes to embody what remains susceptible to misuse and hence waste, that her 
performance of decadence is, from the start, impossible. This impossibility is given a theoretical elaboration in Georges Bataille's notion of unproductive expenditure, a notion which seems to align Bataille himself with the politics of decadence (through his celebration of non-utilitarian expenditure), and therefore, shares in excluding Lulie/women from its transgressive realm. It is because a woman's creation of unproductive values depends upon the fact that there is something about her subject to loss that she is precluded from playing a decadent subject.

\section{1 but for pleasure}

"How long will you stay in India?"

"Oh, I'm not coming back."

"Not coming back! That's impossible."

(Olive Schreiner, "The Buddhist Priest's Wife")

“The sharpest, most violent stimulus, we may say, the true essence of pleasure, lies in some gratification which has no claim whatever, in any sense, to be beneficial or useful, or to have any ulterior motive, conscious or instinctive, or any lasting result, or any fulfilment of any object, but which is simple gratification and dies naturally in its own excess."

(Victoria Cross, “Theodora: A Fragment”)

"not alone, Prince - with someone to explain things - someone who knows all about it - and in this lovely spring weather. You see, I am a bad traveller. .."

(Vernon Lee, “The Legend of Madame Krasinska”)

The story's title already prefigures and encapsulates Lulie's transgressions; it already attributes a certain impossibility to the heroine's excursion into the pleasurable. What the title indicates is that pleasure lies outside the domain of the home, that it belongs to the foreign, into which one has to venture in order to taste it. It involves a journey into a more attractive territory, a relocation from the homely; that is, from the familiar and plain, into a zone of unfamiliarity and indulgence. The domestic, which is always also feminine according to Victorian middle-class gender politics, is a common-place of the mundane and the moderate. Mayne, for instance, expresses this point when he convinces Campbell that Lulie's indulgent pilgrimage will be followed by a return home: "When she's had her fling, I suppose she'll go and marry him [her fiancé]" (71). It is, then, negatively contrasted with the public space, which affords pleasure, and which also genders this pleasure as masculine. Thus Lulie's escapades into the realm which is not hers will be marked by deprivation. 
Her pilgrimage in search of pleasure is a risky enterprise, not only because Lulie must leave the confines of homely safety, but because in leaving it she leaves behind her (respectable) femininity. Lulie's pilgrimage, then, renders her out of place, homeless, in a sense, and also morally dubious. Unlike Lulie, Campbell enjoys "the pleasures of his home-coming" (59) when visiting the Schloss, which suggests a different relation to the public realm. He is welcome at Altenau, a familial space of familiarity and moral safety, a hospitable space which receives him as its own. Thus, while Campbell comes to simply inhabit the place, Lulie, not allowed to feel at home in the public sphere, is seen as a trespasser. Lodged in an off-limits territory, she is left to negotiate the discourse attached to travelling women.

Women moving outside the domestic interior indeed provoked sharp comments among the more conservative critics of the late nineteenth century. For instance, in her famous, and unfavourable 1894 article "The New Woman," Ouida (Marie Louise de la Ramèe) ${ }^{5}$ sees travel as a severe threat to womanhood:

Seclusion lends an infinite seduction to the girl, as the rude and bustling publicity of modern life robs woman of her grace. Packed like herrings in a railway carriage, sleeping in odious vicinity to strangers on a shelf, going days and nights without a bath, exchanging decency and privacy for publicity and observation; the women who travel, save those rich enough to still purchase seclusion, are forced to cast aside all refinements and delicacy.

It is said that travel enlarges the mind. There are many minds which can no more be enlarged, by any means whatever, than a nut or a stone. The fool remains a fool, though you carry him or her about over the whole surface of the globe, and it is certain that the promiscuous contact and incessant publicity of travel, which may not hurt the man, do injure the woman. ${ }^{6}$

In Ouida, travelling deprives the woman of both moral and bodily cleanliness. The deprivation resonates with sexual overtones as travel turns what is seductive into what has already been seduced. The shift from "girl" to "woman" - implicitly a 'fallen' one - hints at the loss at stake. For a woman to travel amounts to having had sexual intercourse. The woman who travels forever advertises what/that she has lost (it). The public exposure to which the travelling woman lends herself, and which Ouida finds so objectionable, is an exposure of that loss. Paradoxically, then, the disgrace is not about her presence amidst the "bustling publicity of modern life"

5. Ouida (Marie Louise de la Ramèe), "The New Woman," North American Review 158 (May 1894) 610-19, in A New Woman Reader: Fiction, Articles, and Drama of the 1890s, ed. Carolyn Christensen Nelson (Peterborough: Broadview Press, 2001), 153-160.

6. Ouida, p. 159. 
but about an absence made visible. The seductiveness of being untouched - that Ouida sets against the contaminating proximity of other bodies - turns into a repulsiveness of being defiled. The loss incurred on the way bespeaks a failure to keep her body intact. The travelling woman is robbed of her grace, Ouida tells us, suggesting that there is something unlawfully and forcefully taken from her, and the injury (contrasted with a more ambiguous "hurt") that summons up the physical, points to a material wound at stake in her travels. Moreover, Ouida assures that "the women who travel" have nothing to gain and everything to lose: the latter has already been lost; the former resolved by biological determinism. Travelling may broaden the mind, yet it is only those at the top of the evolutionary and financial ladder who may benefit: capacious minds and pockets are required if travelling is to perform its educational function.

What lurks in Ouida's view of the travelling woman is an economic loss, too. For one thing, the exchange of "decency and privacy for publicity and observation," which compromises her womanhood, yields no profits. For another, leaving behind her privacy, she eludes privatization, thus complicating the question of ownership. The point is not that she is nobody's but that she might be anybody's. Thus her entry into the realm of "modern life" unsettles the marriage economy in which women are defined in terms of belonging. "The promiscuous contact" to which she is exposed offers neither permanence nor possession. In the casual proximity of others she can merely, like Lulie herself, expropriate herself at the cost of her "refinements and delicacy" that leave behind only a bleeding wound.

W. T. Stead, a more favourable critic, who was editor of the Review of Reviews and supportive of New Women, takes travel to represent women's struggle for freedom. He envisages their emancipation in terms of a strenuous and precarious journey:

Having discovered, apparently very much to her own astonishment, that she has really a soul after all ... [woman] is not going to go back to her old position [as man's dependent]. Through whatever stormy seas and across no matter what burning desert marked by the skeletons and haunted by the ghosts of those who have fallen by the way, she will press on, fleeing from the monogamic [sic] prostitution of loveless marriage and the hideous outrage of enforced maternity as Bunyan's Pilgrim fled from the City of Destruction. All social conventions, all religious teachings, and all moral conceptions will have to be reconsidered and readjusted in harmony with this new central factor. 7

7. W. T. Stead, quoted in Ann L. Ardis, New Women, New Novels: Feminism and Early Modernism (New Brunswick and London: Rutgers University Press, 1990), p. 20. 
Stead clearly aestheticizes New Woman's liberating journey. Despite a certain ugliness of the images (and also of failure) she might encounter on the way, there is beauty waiting, alluringly, in a realm which is other than the hideousness of her present condition. The discovery of her soul coincides with a newly acquired aesthetic awareness. Able to discriminate, at last, between the ugly and the beautiful, she will head for the latter. What we are witnessing here is a scene of risky departure set in a picturesque, if terrifying, scenario of formidable obstacles, which, Stead seems to caution, may or may not be conquered. Determined, as she "will press on," and undeterred by others' failure, the New Woman is depicted as embarking on an almost frantic flight. In Stead's vision, this journey is, potentially, a dead-end one: her threatening reality either disintegrates into ghastly remains or is turned into a threadbare, spectral form with no prospect of advancement. What sounds, in Stead's words, like a believable scenario, strikes a note of disbelief as woman is cast into a disappearing figure. Represented in images of what is/has gone - "ghosts" and "skeletons" - the New Woman, interestingly, claims no return. Left to decay as she withers on the way, or spirited into a movement of incessant returning, "she is not going to go back" anyway. Thus built into her rebellious creed is, as Stead knowingly envisages and as Lulie demonstrates, a one-way journey.

Campbell literally produces Lulie's beauty, a gesture which is in contrast with Lulie's unproductive pilgrimage. She can neither do beautiful things nor can she make things beautiful. The point is not only that she unlawfully ventures into the public space but also that she is incapable of its productive inhabitation. Unlike Campbell, who comes to Schloss Altenau "for a second quiet season with his work" (58), and hopes to spend a "profitable" (58) time there, Lulie inhabits the space squandering the possibilities it offers. Her exclusion from production marks her entrance into the narrative space. "She doesn't travel for profit, but for pleasure" (66), Mayne informs Campbell and readers, confining Lulie to cultural barrenness. He thus differentiates between good and bad travelling, the former being about measurable doing, the latter about triviality and fruitlessness. The differentiation is gender-inflected and emblematic of the masculinisation of travel with its underlying ethos of purpose, which always aims at the productive. As James Clifford argues, "The marking of 'travel' by gender, class, race, and culture is all too clear. ... 'Good travel' (heroic, educational, scientific, adventurous, ennobling) is something men (should) do. Women are impeded from serious travel."8

It could as well be said that women are impeded from all kinds of travel. Not because they have not travelled, but because travel is, as Georges Van Den Abbeele's

8. James Clifford, quoted in Janet Wolff, Resident Alien: Feminist Cultural Criticism (New Haven and London: Yale University Press, 1995) p. 122. 
discussion of the notion of travel demonstrates, ${ }^{9}$ conceptualised in masculine terms. The banality of Lulie's travels is counterposed to the seriousness of Campbell's. Her travels are wasteful as she will neither engage in intellectual labour nor reap any profits. In Mayne's logic, her pleasure has no value that could be measured with either gain or loss. It is purposeless and useless, rendered trivial, a violation of productivity that comes to define the public space.

For a number of reasons, Lulie's travel is bad travel because it fails to emulate the ethos of what, in the nineteenth century, counted as acculturating experience. Lacking in seriousness that can only be granted by "work" done while travelling, it turns Lulie into a loiterer, indolent, unproductive, and solely interested in "[acquiring] new sensations" (66). Mayne's dismissive remark not only downplays her pleasure-pilgrimage but also locates the narrative within the production/consumption dichotomy, which, in turn, corresponds to a distinction between two different kinds of travelling that James Buzard characterises as "genuine and spurious cultural experience."10 The former refers to "true travellers;" the latter to "mere tourists." ${ }^{11}$ Buzard has shown how the nineteenth-century travel discourse persistently aligned women with tourism marked by "a misuse of the acculturating potential of travel." 12 Wasting the possibilities travelling offers, a (female) tourist is also dedicated to "attention-getting displays" 13 of herself, unlike a true traveller who always prefers "polite self-effacement." ${ }^{14}$ Lulie's spectacular apparel and appearance testify to the tourist's desire to produce a sensational sight out of herself. Indeed, being watched was part and parcel of feminine touristic experience. As Buzard argues, woman "was a natural tourist to the men who observed her: she was another avatar of that plural person destroying real travel. .."15 Thus, in terms of the Victorian gender politics of travel, Lulie's own pilgrimage can only be read as a sign of frivolity and triviality.

"The urge for travel is the urge for 'experience', with all its alarming connotations for the proper fathers of ripening daughters," ${ }^{16}$ writes Buzard, pointing to the risky component of anti-tourism (unobjectionable in the case of men) which worked to exclude women from the realm of travelling. Experience, including sexual experi-

9. Georges Van Den Abbeele, Travel as Metaphor: From Montaigne to Rousseau, (Minneapolis and Oxford: University of Minnesota Press, 1992).

10. Buzard, p. 80 .

11. Buzard, p. 81.

12. Buzard, p. 140.

13. Buzard, p. 96.

14. Buzard, p. 96.

15. Buzard, p. 151.

16. Buzard, p. 147. 
ence, was understood to be part and parcel of touring, a fact which placed women on the move in a precarious position. ${ }^{17}$ While Lulie's "rich father somewhere away back in Michigan" (65) is absent (which actually makes her even more vulnerable to what Ouida called "promiscuous contact"), she nonetheless finds herself in the paternal company of Mayne and Campbell, whose solicitude about her exploits clearly evokes the connotations at stake: "And she's been travelling about since last May: Paris, Vienna, the Rhine, Düsseldorf, and so on here. She must have had some rich experiences, by Jove, for she's done everything" (65).

Deprived of proper fatherly supervision, Lulie becomes a collector of the most extraordinary, and purportedly perilous, experiences gaining knowledge she is not supposed to possess. Yet these experiences, culled from a number of visits, come to thwart Campbell's expectations about Lulie's innocence and ignorance. Perceived as a worldly woman whose travels are motivated by a desire to "amuse herself" (66), Lulie invalidates Campbell's claims to visual and cultural mastery.

While in the story Lulie is, undeniably, on a journey around Europe, travelling from place to place in search of adventures, the narrative itself turns her into a visited land, a territory to be explored and discovered in a travel-like fashion by the collectors of feminine beauty in pursuit of aesthetic experiences. As Margaret Stetz notices, imperial imagery underwrites Campbell's aesthetic appreciations of Lulie: "The narrator's language exposes the easy slippage from the seemingly apolitical world of art collecting and accessions to imperial conquest and domination, as Campbell fancies himself the 'discoverer' of, quite literally, virgin territory."18

The link between the aesthetic and the imperial was, as Deborah Cherry demonstrates, a powerful component of the colonial project. "Pictorialising," the key term Cherry uses to characterise the visual attitude and conception of the colonial space, not only framed that space and its people "within the European visual systems" but also "rendered them intelligible within them." 19 The transformation of "sites into sights," ${ }^{20}$ the central strategy of (economic) exploitation, involved a violent gesture of "landscaping." It is the category of landscape, a turning of "earth into world, land into visual culture . . restructur[ing] land for leisure and tourism as well as visual and spiritual refreshment, sensory pleasure and a pictorialising vision," ${ }^{21}$ which best represented the colony's "pictorial disposition." ${ }^{22}$ This disposi-

17. Buzard, pp. 130-132.

18. Stetz, p. 37.

19. Deborah Cherry, Beyond the Frame: Feminism and Visual Culture, Britain 18501900 (London and New York: Routledge, 2000), p. 80.

20. Cherry, p. 79.

21. Cherry, p. 77.

22. Cherry, p. 85 . 
tion entails that the land is "uninscribed," offering availability and inviting new forms of arranging. The aesthetic pleasure generated by the turning of land into landscape was inseparable from "the fantasies of possession and exploitation." ${ }^{23}$ The turn, Cherry further argues, was not only about re-inscription but also about framing the land "within a pre-existing pictorial order." 24

In Campbell's visual practice Lulie emerges as an eroticised beauty. Lulie, who had "the most singular eyes he had ever seen; slit-like eyes, set obliquely in her head, Chinese fashion" (60), undergoes an imaginary relocation which mobilises a set of recognisable associations and establishes positions where she is turned into the object of a typically decadent fantasy of the exotic "consumable 'foreignness." " 25 Reduced to an emblem of exoticism, Lulie's eyes become the figure of the unfamiliar, the strange, the locus of the elsewhere which Campbell tours, in a colonial fashion, in order to frame it. The construction of Lulie as otherworldly binds the aesthetic to exoticism: figuring as an Orientalised beauty and thus transcending the here and now, she embodies the necessary distance from the familiar everyday which was seen as contaminating 'true' art. Detached by Campbell from the banality of the common and aligned with the exotic she also assures his position as an aesthete par excellence. As Felski argues, "the aesthete seeks to differentiate himself from the dull mediocrity of modern society by taking refuge in the solitary cultivation of the arcane and the exotic." ${ }^{26}$ At the same time, this differentiation becomes a badge of his exquisite taste and uniqueness. ${ }^{27}$

Thus to cast Lulie within a frame of exoticism is also to summon relations which such a framing implies. The evocation of the exotic provides a setting in which the parts to be played are couched in an imperial language. As Stetz aptly notices, Campbell imagines himself as a self-appointed discoverer and author of Lulie's beauty. Lulie, in turn, figures as an un-inscribed, pure territory facilitating Campbell's superior I/eye. ${ }^{28}$ In this relationship, it is Campbell who emerges as the real traveller - Lulie, quite evidently, relegated to the realm of stasis: "his eyes travelled over to . . . where she sat" (69). Campbell's rambling eyes, perusing Lulie's immobile body, usurp vision creating thus a relation that denies her the status of a traveller. Here, seeing and travelling converge to produce an amorous conquest with Campbell as its subject and Lulie as its object. Campbell's pictorial perception of

23. Cherry, pp. 87-90.

24. Cherry, p. 98.

25. Rita Felski, The Gender of Modernity, (Cambridge and London: Harvard University Press, 1995), p. 140.

26. Felski, pp. 98-99.

27. Felski, pp. 98-99.

28. Stetz, p. 37. 
Lulie, performed in the mode of exploration, which necessarily immobilizes her, assures her passivity for Campbell's active role. Lulie, who is reduced to an item of exoticism, can yield to Campbell's aestheticising, creative gaze as she is assumed to be a neutral, blank page of territory waiting for inscription. As Felski notes, the exotic space, so often evoked in fin de siècle culture, gained much of its appeal due to its atemporal character. ${ }^{29}$ In Campbell's imagination, Lulie is both outside and without history. Indeed, this assumption becomes a precondition for his fascination, which will, with time, wear away once he learns she not only has a history but indeed one of her own fashioning.

For Lulie, to leave the confines of the domestic is inevitably for the pleasure of others. If her own claims to pleasure are illegitimate, her fate as a pleasurable spectacle is fully sanctioned even though it is not taken for granted at the beginning. Indeed, her value as an aestheticized object is measured by her capacity to (dis)please, and vice versa - the (dis)pleasure she affords depends on how beautiful she can get. It is, obviously, Campbell who fixes the limits of her beauty. His initial uncertainty of Lulie's aesthetic worth is gradually dispelled as he transforms her into a collection of picturesque surfaces, a pictorial vista of "something altogether unique" (64): "the uncurled wisp which strayed across her white forehead was soft and alluring ... soft masses of it tucked up beneath her hat-brim. ... When she suddenly lifted her red-brown lashes, those queer eyes of her had a velvety softness too. Decidedly, she struck him as being pretty - in a peculiar way" (62-63).

Campbell's careful assessment, which brings about this miraculous transformation of undecided attractiveness into unquestionable beauty, mirrors the progression of pleasurable sensations. "The pleasure he did not feel" (60) - on first meeting the ladies - undergoes a revision as he begins to discern Lulie's beauty: "Her strange little face, with its piquant irregularity of line, its warmth of colour, began to please him" (62). What underwrites his pleasure is both aesthetic appreciation and complacency for Campbell, in an authorial fashion, takes full credit for beauty's discovery: "It seemed to him that he was the discoverer of her possibilities. He did not doubt that the rest of the world called her plain, or at least odd looking. . . . Campbell saw superiority in himself for recognizing it [beauty], for formulating it; and he was not displeased to be aware that it would always remain caviare to the multitude" (63).

Thus Lulie is not merely an occasion for Campbell's aesthetic indulgence; she is a test for his aesthetic abilities and expertise. But to enable this expertise she must remain neutral, both for herself and others, unmarked by beauty or ugliness that are as yet to be inscribed upon the surface of her body. What assures this neutrality is a

29. Felski, p. 136. 
certain blindness: for to enable Campbell's superior vision it is required that Lulie does not see (herself). Thus pondering upon Lulie's perception of herself, Campbell assumes her inability to formulate her own beauty, which is predicated upon an incapability of self-seeing:

He wondered now what she thought of herself, how she appeared to Nannie. Probably as a very ordinary little girl; sisters stand too close to each other's qualities. She was too young to have had much opportunity of hearing flattering truths from strangers; and besides, the average stranger would see nothing in her to call for flattering truths.

Lulie's blindness partakes of patriarchal mythology where visual deprivation becomes women's property, a defining principle that marks their bodies and conditions their habitation within its logic. To use Naomi Schor's words slightly out of context, "Beauty's blindness underwrites two potent and complementary myths of misogyny: first, that women should be seen rather than see; second, that despite their beastly appearance, men possess an inner beauty waiting to be revealed." 30

And yet, amidst the connoisseurship to which she is exposed, Lulie powerfully defies the imperial logic that assumes her blindness, that frames her into a sightless and mute surface subject to aesthetic exploration. Lulie's discreditable past sketched so vituperatively by Mayne and endorsed by Campbell works to unmask the logic of what Stetz calls "masculine aesthetic practices." ${ }^{11}$ It is against this past, glimpses of which can be caught during Lulie's sojourn at Altenau, that Campbell's attempts at the pictorial appropriation of Lulie are made visible and futile. Revealed at the beginning of the story, and substantiated throughout its course by Lulie herself, this past allows us to see how Campbell's artistic expertise stumbles over Lulie's self-fashioned history that persistently refuses to yield to his mastering discourse. For while the conflicting narratives criss-cross in an upsetting encounter, Lulie slips off (in the end, quite literally) the picture she is meant to represent. Campbell, cast by the imperial discourse, into the role of an explorer, never comes to conquer the presumably passive Lulie/land. Lulie speaks back, refusing the muteness inscribed onto her body by the metaphors of colonial conquest. Her resistance also disturbs the production/consumption paradigm on which the narrative's gender relations rest, for Campbell, in the end, proves unproductive of beauty and hence incapable of validating his presence within the public domain.

30. Naomi Schor, "Blindness as Metaphor," differences: A Journal of Feminist Cultural Studies 11.2 (1999) 76-105, p. 88.

31. Stetz, p. 40. 
OF WOMEN AND DECADENCE

\section{2 you don't know what you have lost!}

Mademoiselle, listen to me! Does it hurt when you lose your body?

(Jean Lorrain, “The Unknown Lady”)

I felt there was no price I would not have paid to have stood for one half-hour in intimate confidence with her, and been able to tear the veils from this irritating character.

(Victoria Cross, "Theodora: A Fragment")

If a man loves a woman he has a right to try to make her love him because he can do it openly, directly, without bending. There need be no subtlety, no indirectness. With a woman it's not so; she can take no love that is not laid openly, simply, at her feet. Nature ordains that she should never show what she feels; the woman who had told the man she loved him would have put between them a barrier once and for ever that could not be crossed;

(Olive Schreiner, “The Buddhist Priest's Wife”)

Only consumption and tuberculosis still kill.

(Jean Lorrain, “The Man Who Loved Consumptives”)

Lulie Thayer could be seen as a typically decadent femme fatale. Dangerously beautiful, boldly seductive, sexually rampant, with "buccaneering instincts (84), a perverse collector of carnal sensations and men, she flirts "for mere devilry, for a laugh" and "goes about seeing how many masculine hearts she can break" (68). In a sport-like fashion, she measures her success with the "spoils" she can get. Men become a list of "a long succession of names," whom she dupes seductively with "unblushing coolness" (67):

Mayne fetched an alpenstock from a corner of the hall; it was decorated with a long succession of names, which ribbon-like, were twisted round and round it, carved in the wood. "Read them," insisted Mayne, putting the stick in Campbell's hands. "You'll see, they are not the names of the peaks she has climbed, or the towns she has passed through; they're the names of the men she has fooled.

Lulie represents moral decay, which may not mean death for the men she encounters but which is infectious enough to place them in a precarious position. If she does not threaten their lives directly, she threatens their rational sobriety for "the men she has fooled" can only become susceptible to fooling once they are imagined as literally losing their minds. Mayne, who himself has been imperilled 
by the charms of the seductress, recollects the moment as one jeopardising his ability to think: "It took me a minute or two to recover the presence of mind..." (67). The loss thus enacts a moment of emasculation, which through this momentary suspension of reason amounts to a metaphorical decapitation echoing the decadent metanarrative of Salomè and John the Baptist.

The deprivation which un-mans Lulie's flirts also disrupts the relation between seeing and knowing as the gaze lavished upon Lulie's beautiful body no longer secures adequate knowledge. Insight does not follow seeing, for what the men she has fooled have been unable to see is Lulie's duplicity. Because Lulie does not easily yield to Campbell's imperial gaze, she disrupts the relation between knowing and mastery. Campbell, in turn, subscribes to a logic where "seeing is the origin of knowing" and "knowledge is gained through vision" while "vision is a direct, unmediated apprehension of a world of transparent object." ${ }_{2}$ This assumption, which Campbell bears out, leads to confusion, for what he sees is painfully at odds with what he knows:

He could feel nothing but dislike for her - disgust even; and yet he was conscious how pleasant it would be to believe in her innocence, in her candour. For she was so adorably pretty; her flower-like beauty grew upon him; her head, drooping a little on one side when she looked up, was so like a flower bent by its own weight. The texture of her cheeks, her lips, was delicious as the petals of a flower.

The sense of disappointment comes already with Mayne's elaborate story of Lulie's romantic and other exploits. Campbell is left to come to terms with the discrepancy between surface and depth, between his vision of Lulie and the contents of her marvellous, pure body: "Campbell's impressions of the girl were readjusting themselves completely... He wished with all his heart that Mayne would stop, would talk of something else, would let him get away. The young girl had interested him so much; he had felt himself so drawn towards her; he had thought her so fresh, so innocent" $(66,67-68)$.

Despite Campbell's attempts to inscribe innocence onto Lulie body and into her history, she assumes the decadent posture of an aesthete offering judgment on beautiful things and men. Thus she deems the castle, to Campbell's disagreement, "So wonderfully picturesque," its frightening medieval interior "delightful" and "lovely" (61). She also subjects Campbell to her appraising gaze as she comments on his beauty: "You have such blue and boyish eyes, you know" (76). This

32. Joan W. Scott, “'Experience,' " in Feminists Theorize the Political, ed. Judith Butler and Joan W. Scott (New York and London: Routledge, 1992), 20-40, pp. 23-24. 
indulgence in appreciation culminates in Lulie's exercise of aesthetic taste as she places Campbell amidst other men in order to single him out as the most pleasurable: "I've always known a lot of young fellows who've liked to take me round... And I enjoyed it, and there wasn't any harm in it, just kissing and making believe, and nonsense. But I never really cared for one of them - I can see now, when I compare them with you" (82). In Stetz's words, "from her opening speech, Lulie lays claims to spectatorship... She shows an easy familiarity with the aesthetic credo, preferring artifice to nature..."33 Indeed, Lulie comes to express this preference most pronouncedly associating truth with lack of aesthetic value.

Unlike Lulie, who, in a truly decadent fashion, declares that "Truth is so uninteresting!" (69), Campbell stubbornly insists on a sheer truth that, he believes, must lie somewhere beneath the veneer of theatricality Lulie performs. Throughout the story, Lulie never steps off the stage, introduced first as a flirtatious liar acting "always and to everyone" (74), and then withdrawn as "the most consummate little actress," whose role "demanded a sensational finale in the centre of the stage" (84). Claimed "an actress, a born comedienne" (74), she harbours a "histrionic sense of the fitness of things" (84). Her behaviour "well-simulated" (72), her actions "excellently contrived" (74), Lulie "chooses to pose" (74), complicating her relationship with men who opt for transparency, who, as in the case of Campbell, aim to expose her masquerades where her innocent appearance and speech conceal a terrifying, "monstrous, preposterous" (72) reality. The narrative, in fact, revolves around the tension between Campbell's obsessive belief in truth, which he believes he can masterfully tell from duplicity, and Lulie's refusal to submit to this logic. Because Campbell differentiates between sincere self-presentation and deceitful theatricality he will spend his narrative time searching for, and bemoaning the loss of, Lulie's authentic self hidden behind the costume of artificiality she wears so scandalously.

Campbell reproduces, therefore, what Barbara Spackman refers to as "a hermeneutic model" where "appearance conceals reality, surface conceals depth, artifice conceals truth, rhetoric conceals plain speech and reference," 34 thereby turning Lulie into a model of hermeneutics. As she comes to embody this model, Lulie substantiates yet another logic, mentioned by Spackman, according to which the concealed is revealed as femininity par excellence. Indeed, as Spackman further argues, what belies the collection of these concealments, is sexual difference. Referring to Derrida, Spackman restates that "the truth" masked by

33. Stetz, p. 39.

34. Barbara Spackman, Decadent Genealogies: The Rhetoric of Sickness from Baudelaire to D’Annunzio (Ithaca and London: Cornell University Press, 1989), p. 39. 
artifice, "is the 'truth of woman,' " a principle which finds its most graphic representation in the "figure of the enchantress turned hag ... in which an alluring enchantress . . is revealed to be a toothless hag." 35 It is this revelation of a monstrous, "tarnished ... beauty" (73) that comes to replace the seductive "flowerlike beauty" (70), that brings out the lurid truth about Lulie.

Campbell persistently subjects Lulie to the imperative of truth-telling. Yet the more she speaks the less truthful she is; the more she talks, the less she says. As Jane Gallop eloquently argues,

In the ideology of our culture women are objects described, not speaking subjects. Women as women, as incarnations of the myth of Woman, do not produce culture. Woman was never considered to be actually nonspeaking. Talking constantly, women emitted chatter, gossip, and foolishness. Naïve men were ensnared by the siren's song, because they took the woman at her word, taking that word out of the context of its unending protean flow. So women were called liars, and their speech, not conforming to male rules of logic, clarity, consistency, deemed nonsense. . . Women could not be trusted to tell the truth about themselves. ${ }^{36}$

The love-chatter Lulie keeps emitting fails to convey true meaning. In Campbell's idea of meaningful speech, loquacity and truth do not go together. What is veritable, that is, believable, calls for restraint, for a moderate expression which shuns superfluous flow. Feminine truth originates in taciturnity, in a modest production of words, which Lulie never comes to recognise. Thus Campbell, for whom "the damnable iteration of the one idea became monotonous" (76), grows impatient with Lulie's continual "But I love you" (82) which bespeaks an improper excess in place of the properly feminine reserve. He will muse, therefore, that "real love," requires "reticences" and is "full of delicacy" (75). Real love abides in verbal restraint and discretion; it avoids ostentation, knows restraint, and does not offer un-called for speech. Campbell, forewarned by Mayne not "to fall prey to the wiles of this little American siren" (77), continues to disregard Lulie's confessions. Since she fails to procure silence, she is bound to remain unheard.

Her speech, like her pilgrimage, trespasses upon the ethos of (self)restraint, exceeding the limits of acceptable femininity. Lulie's annoying, useless babble proves totally unproductive (here, of sense, of meaning) also because it is addressed, promiscuously, to "every man she meets" (67). Her excessive talk par-

35. Spackman, p. 39.

36. Jane Gallop, Thinking Through the Body (New York: Columbia University Press, 1988), p. 71. 
takes of an economy which ignores temperance in favour of consumption and reckless expenditure. Driven by a ravenous appetite for new sensations, she consumes places, men and desire. Cultivating a taste for "new ways of kissing" (66), she abundantly offers kisses (Campbell reproachfully asks: "How many men have you not already kissed, even since you've been here?” [72]) that symbolise Lulie's consumption of pleasure, the underlying principle of which is waste. Given away, to everyone, at no cost, and against the logic of marriage economy, these kisses violate the proper relations that should lead to the production of legitimate matrimonial felicity.

Right at the beginning, Mayne, drawing a portrait of Lulie's peculiar conduct and in a way advertising her to Campbell, foregrounds her alignment with loss, excess and wastefulness. In this realm of economic transgression beauty becomes attractive once it is not properly guarded, but is, instead, spent and generously dealt out: "Though it's not so much her beauty," Mayne continued. "After all, one has met beautiful women before now. It's her wonderful generosity, her complaisance. She doesn't keep her good things to herself. .." (64).

Presumably, liberal of her body, Lulie shares out what materially, physically constitutes her beauty, and what, when kept, and saved for restricted interest, is not subject to a generous dispensation. Mayne's remark implies that, in the first place, there are things Lulie should keep to herself, things she should make neither visible nor shareable. These good things, for Campbell, become an equivalent of her beauty, something that literally makes it up and guarantees certain benefits. Thus in his numerous and eloquent vituperations Campbell bemoans Lulie's imprudent, careless squandering of her things. Here, the waste of purity is concurrent with the waste of beauty, the two assets collapsed into one property, virtually beyond distinction:

And you don't know what you have lost! You have seen a fruit that has been handled, that has lost its bloom? You have seen primroses, spring flowers gathered and thrown away in the dust? And who enjoys the one, or picks up the others? And this is what you remind me of - only you have deliberately, of your own perverse will, tarnished your beauty, and thrown away all the modesty, the reticence, the delicacy, which make a young girl so infinitely dear.

Lulie is censured for discarding, destroying things that could, otherwise, flourish in usefulness, things whose real value materialises in legitimate use defined by someone other than herself. It is this use she never comes to recognise, that makes woman dear, that is, beloved and costly at the same time. Lulie unlawfully throws away something precious, becoming worthless, no longer useful, a 
moral bankrupt who has nothing to offer, nothing that could serve the desired end of marriage. So Campbell will reiterate, to himself: "So much youth and beauty tarnished; the possibility for so much good thrown away" (78).

The idea that Lulie has irretrievably lost something is combined with Campbell's conviction that she does not know what it is that she lost. He returns to this point once more, deploring her profligate kiss-giving: "To me," said he, "to all right-thinking people, a young girl's kisses are something pure, something sacred, not to be offered indiscriminately to every fellow she meets. Ah, you don't know what you have lost!" (73).

Lulie's wastefulness, her deliberate wasting of what should be spared for one pair of hands only, is motivated by her failure to understand the rules of marriage economy, to understand how the good things should be used. What Lulie does not know is that she is not the one who decides on their usage. The violation of moral propriety that Lulie brings about results from the usurpation of the good things with which bourgeois marriage economy has credited her. It is because she appropriates what, traditionally, she does not own, thereby placing herself in a position from which she dispenses it at will, that she is put beyond the pale. Lulie is ignorant of the rules of economy in which her good things are not quite hers, even though they belong to her by dint of her (physical) constitution.

With her unproductive pilgrimage and speech, her wasteful and unrestrained consumption, the losses she incurs on the way, and even her inability to produce a successful Victorian plot, Lulie could be seen as an exponent of unproductive expenditure, an idea elaborated by Georges Bataille, 37 and considered an alternative to Thorstein Veblen's theory of utility and productiveness. It turns out, however, that Bataille's challenge to bourgeois values, and the economy that produces them, assumes a particular subject that can take it up. This assumption excludes women from the benefits of the transgressive potential this challenge offers.

As John Frow argues, Bataille's notion of unproductive expenditure, exemplified in the institution of potlatch, is a theorisation of "antieconomic and antiutilitarian excess" 38 whose value is waste or loss. Since the various forms of unproductive expenditure entail discharge of "a bodily waste or wealth doomed to uselessness," 39 it is ultimately the category of waste that is given the greatest value in Bataille's theory. And yet, as Frow remarks, the category of waste cele-

37. Georges Bataille, "The Notion of Excess," in Visions of Excess: Selected Writings, 1927-1939, ed. Allan Stoekl (Manchester: Manchester University Press, 1985), 116-129.

38. John Frow, "Invidious Distinction: Waste, Difference, and Classy Stuff," in Culture and Waste: The Creation and Destruction of Value, ed. Gay Hawkins and Stephen Muecke (Lanham: Rowman \& Littlefield Publishing Group, 2003), 25-38, p. 32.

39. Frow, p. 32. 
brated by Bataille for its potential to subvert bourgeois economy, does not succeed, ultimately, in escaping this economy's logic. What Bataille's theory of unproductive expenditure demonstrates, Frow continues, is precisely the futility of a possible transcendence of utility and profitability:

What seems to me to be demonstrated by the failure of Bataille's radical attempt to find a way out of the restricted economy of social interests is the impossibility of imagining a point that exists outside of economy. No object can be withdrawn from its uses, isolated in a space beyond social interest, and indeed even the absolute loss that Bataille envisages can and will ultimately be put to the ends of gain. ${ }^{40}$

Further, pointing out the indispensability of the notion of waste to the theories of value, Frow writes: "Waste is the degree zero of value, or it is the opposite of value, or it is whatever stands in excess of value systems grounded in use." ${ }^{11}$ Thus waste is what exceeds the parameters of usefulness, an excess value-neutral or value-less, and uselessness is what defines it. And yet despite its seeming lack of value, waste is, Frow continues, "constitutive of the structure of value;" it is "residually a commodity," 42 something that always retains the potential for profit, that might still come into use and thus value. Thus the meaning "waste" conveys is to some extent deceitful in that there can be no absolute waste which could be posited, once and for all, as an opposite to utility and usefulness. To say that waste is "residually a commodity" is, it seems, to say two things: that waste (excess) is stipulated by the very economy it sets out to evade and that, therefore, it can be co-opted by the values it defies. Indeed, in his short text "The Notion of Expenditure" Bataille ultimately fails to escape the economy of utility, and in particular, the bourgeois marriage economy. It is precisely at the point where Bataille mentions woman that his indebtedness to this economic contract (one that comes to circumscribe Lulie herself) is given away. It is not only that Bataille's notion of "anti-economic and anti-utilitarian excess" reproduces a set of gendered metaphors, but that it rests on a relation where woman is the property of man by dint of having something that is traditionally placed in his hands, something that subjects her to expropriation and that can be lost, taken away either against or in accordance with the rules of economy, yet still only within its logic, and for use within its parameters.

Bataille's notion of "non-productive expenditure," set against rational acquisition and consumption, is a celebration of "considerable losses" in the name of 
"the satisfaction of disarmingly savage needs." 43 This act of satisfying what surpasses the limits of civilising control is an attempt to go beyond the "utilitarian justification for his [man's] actions," 44 which is, beyond an oppressive father-son relationship, where the son, in unquestioning obedience to his father, is denied the right to articulate his pleasures, and "express his will." 45 Thus non-productive expenditure originates in the negation of the father and a violation of the fatherson bond (the son "indulges in his unavowed pleasures as soon as he is no longer in his father's presence"46); it requires the father's absence for the son's nonproductive expending, and becomes possible when "the father's interest" 47 gives way to the son's pleasures extricated from the utilitarian fatherly mantle.

Bataille distinguishes between two kinds of consumption. The first is a form of sustenance that keeps people alive and active, that conditions productive activity. It is a consumption in the service of production. Bataille writes, "the use of the minimum necessary for the conservation of life and the continuation of individuals' productive activity." 48 The other involves unproductive expenditure, activities which "have no end beyond themselves," 49 which neither produce nor further production, which are, therefore, in excess of the bare necessities of life. What underlies this expenditure is a loss, subversive of an economy of "balanced accounts" where what is expended always returns in the newly acquired. This loss becomes constitutive of unproductive expenditure, whose primeval forms Bataille locates "in primitive economic institutions" 50 where the need to lose, and not the need to acquire, dominates exchanges.

Bataille argues that in the market economy forms of exchange have been dissociated from unproductive expenditure and have come to be dominated by "an acquisitive sense." ${ }^{1}$ Fortunes became stabilised and immunised to losses. Nevertheless, expenditure is still the aim of economy though it is carried out "in obscurity," a shameful activity ("as belching") that is best hidden away lest it should betray signs of an appetite satiated beyond propriety. Driven by the rules of "functional and restrained expenditure," ${ }^{2}$ the bourgeoisie renounces the exces-

43. Bataille, p. 117.

44. Bataille, p. 117.

45. Bataille, p. 117.

46. Bataille, p. 117.

47. Bataille, p. 117.

48. Bataille, p. 118.

49. Bataille, p. 118.

50. Bataille, p. 121.

51. Bataille, p. 123.

52. Bataille, p. 124. 
sive and brings expenditure under rational control. There is an implicit affinity between unproductive expenditure and an unrestrained bodiness (the "generous" and the "orgiastic" define what has been wasted by the bourgeois) whose incalculable excess, Bataille suggests, has been subjected to the decency of the bourgeois household. In the bourgeois era the display of wealth, and hence expenditure, becomes privatised ("wealth is now displayed behind closed doors" of the bourgeois home and "in accordance with depressing and boring conventions" 53 ) and conventionalised. Privatisation of expenditure means the loss of its unproductiveness, the private the end of excess and generosity, the façade of ostentatious spectacle compromised to the "sordid and rapacious face" 54 of the bourgeois (home).

What Bataille bemoans, therefore, is the fact that under the bourgeois economy, unproductive expenditure has been domesticated, that is, stripped of its subversive potential and subjected to the conventionalising regularities of the home. The household is not a place hospitable to excess because excess needs (a) public(ity) for its manifestations. The private is a space of obscurity, of invisibility that by this very fact reduces what falls within its territory almost to nonexistence. It is not a space where expenditure can retain its unproductive quality since for Bataille the household signals a return to the values of the bourgeois. In Bataille, domestication inaugurates what Rachel Bowlby has eloquently discussed as a regrettable regress to "dominant culture" 55 when a given theory or idea is said to be domesticated:

Once someone or some idea is deemed to have been sent home ... it is as if there is no more to be said. The front door closes definitely on a place removed and retired from the open air of its previous existence.... If a theory gets domesticated, that's the end of it. It becomes like everything else... 'domestication' is used to signal something unproblematically negative that happens to a theory, when - what? - well, when it loses its radical edge, gets tamed, is co-opted or institutionalised. ${ }^{5}$

Yet despite the limitations of "reasonable conceptions" 57 (such as functional expenditure) which appear to produce "closed systems" ${ }^{8}$ organising human life,

53. Bataille, p. 124.

54. Bataille, p. 125.

55. Rachel Bowlby, "Domestication," in Feminism Beside Itself, ed. Diane Elam and Robyn

Wiegman (New York and London: Routledge, 1995), 71-92, p. 74.

56. Bowlby, p. 73.

57. Bataille, p. 128.

58. Bataille, p. 128. 
there are always, Bataille argues, possibilities of transgression intimated in the system's "deficit" 59 that open up spaces for the labours of "insubordination" "the immense travail of recklessness, discharge, and upheaval." 60 Thus the acts of recalcitrance involve a laborious effort to elude predictable ends and so avoid subordination to anything in advance. The immense travail, for one accountable end at least, that is, the insubordination, requires an "illogical and irresistible impulse" 61 which allows one "to reject material or moral goods that it would have been possible to utilize rationally." 62 This impulse to transcend bourgeois reason manifests itself in what Bataille calls "the states of excitation" 63 comparable to intoxication, which defy the logic of balanced accounts, of utility governed by rationality. It is only when one yields to this illogical and irresistible impulse that resists expenditure governed by reason that loss can emerge as value. It is only when one rejects goods, which could be put to some rational use, that losses can be "realized." Extricating expenditure from usefulness Bataille aims to offer an alternative value of unproductiveness. Thus instances of rejecting what might be recuperated in utilisation lead to a valuable effect where what is lost, wasted, contributes, nonetheless, to production: "connected to the losses that are realized in this way - in the case of the 'lost woman' as well as in the case of military expenditure - is the creation of unproductive values." 64

The origin of unproductiveness is the rupture of the father-son bond, a bond that occurs between men, where the father must disappear, abdicate, so to speak, in order to give way to another man (father). Women are excluded from this important relation and its disruption (Bataille does not speak about any other relationship) but are, nonetheless, to return as figures for unproductive expenditure when the case of the "lost woman" emerges as a site for the production of unproductive value. The case of the "lost woman" is a case of how losses come to be realized. What is lost is the potential for rational utilization of certain goods (Lulie's "good things") according to bourgeois frugality. It is a case where "material or moral goods" are not utilised rationally giving rise to values extricated from bourgeois (sexual) economy. The lost woman is a woman who has lost her reputation, and who has lost it in a place other than the home/marriage. The lost woman is a fallen woman, a woman who has fallen outside the realm of legitimate loss, an "outside" where what she has to lose can be lost irrationally and illogi-

59. Bataille, p. 128.

6o. Bataille, p. 128.

61. Bataille, p. 128.

62. Bataille, p. 128.

63. Bataille, p. 128.

64. Bataille, p. 128. 
cally, against the logic of marriage; that is, uselessly. She is a woman who tran sgressed the boundaries of the reputation guaranteed by her sojourn in the home where the moral good can be consumed without incurring an illegitimate loss. She is a woman whose moral good (the moral good that woman is) has not been consumed in accordance with marriage economy and not in the right place, and has therefore been purposefully wasted. Man does not become Bataille's case because man has no reputation to lose, that is, no reputation to be lost in this way. The moral good (that she traditionally is) forever posits woman as material for waste. Within the sexual economy which credits her with something to lose she can always offer it to be wasted, spent against reason. In other words, to talk about the lost woman is only possible once it is assumed that there is something that she can lose no matter where.

Lulie, called a "wanton" (68) and implicitly rendered as a lost woman (also literally, by the end of the story, through her death), comes to learn the painful lesson of realised losses. The many references to good things wasted, euphemistically evoked as beauty, culminate in Campbell's fiery speech which addresses Lulie's implication in an economic logic, that she, as a woman, cannot transgress. Shortly before her spectacular suicide, Campbell lashes out against Lulie, infuriated with her immodest ways and her ignorance of the economies of feminine love:

"For God's sake, drop that damned rot," he cried out with sudden fury. "It wearies me, do you hear, it sickens me. Love, love - my God, what do you know about it? why, if you really loved me, really loved any man - if you had any conception of what the passion of love is, how beautiful, how fine, how sacred - the mere idea that you could not come to your lover fresh, pure, untouched, as a young girl should - that you had been handled, fondled, and God knows what besides, by this man and the other would fill you with such horror for yourself, with such supreme disgust you would feel yourself so unworthy, so polluted... that... that... by God, you would take up that pistol there, and blow your brains out!" (82)

For all its elaborate rendition, Campbell's point enacts the case of Bataille's lost woman together with its implications that woman is not in a position to defy the economy of "balanced accounts" because this economy needs her as an object both for its re-production and for transgression (a fact that, willy-nilly, assigns to her a utilitarian function). Campbell's rhetoric posits Lulie as a thing that can be taken, if offered at the right time and in the right way, its worth calculated by rules of ownership. Extravagant in speech and conduct, Lulie is brutally reminded that she is the good things she never kept to herself (giving them away unproduc- 
tively) and her mistake was not to recognise that it is brand new things that are valued most. Because too many hands have laid claim to her body, Lulie loses the economic game which credited and equated her with something to lose (either legitimately or not). Acting irrationally, against the role she has been given, against the raison d'être of the game, the only loss she can afford with her unproductive expenditure and excessive consumption is a hurtful wound in her bosom, a hole left by the bullet that bespeaks the loss of her body. 